\title{
Study of ground water quality in tap and hand pump water of Tonk city, Rajasthan, India
}

\author{
Shyam Soni ${ }^{1}$ and R.K. Singh ${ }^{2}$ \\ 1 Bhagwant university, Ajmer (Rajasthan) \\ 2 Supervisor Bhagwant university, Ajmer (Rajasthan)
}

\begin{abstract}
-
Water is basic need of life for all living organism at the earth. To study the drinking water pollution in Tonk city of Rajasthan (India), a total of five water samples were collected from tap and hand pump of various area of Tonk city. The various physical chemical parameters such as $\mathrm{pH}$, chloride, total alkalinity, total dissolved solid and total hardness were analyzed in the water samples to characterize the ground water quality and suitability for drinking purpose. All the water samples were compared with Indian standard of drinking water prescribed by bureau of Indian standard BIS 10500:2012. The physical chemical analysis of water samples of Tonk city showed that $\mathrm{pH}$ value ranged from 7.00 to 7.60 and chloride ranged from 50.24 to $595.96 \mathrm{mg} / \mathrm{l}$. The total alkalinity varied from 185.90 to 452.25 $\mathrm{mg} / \mathrm{l}$. The total dissolved solid ranged from 270 to $2250 \mathrm{mg} / \mathrm{l}$ and total hardness from 146 to 792.96 $\mathrm{mg} / \mathrm{l} . \mathrm{mg} / \mathrm{l}$. The result of physical chemical analysis of water samples of Tonk city indicated that water of Jawahar Bazaar Tonk (S1), Taj colony Tonk (S2), Mehandi bagh Tonk (S4) and Civil line Tonk (S5) were suitable for drinking purpose but hand pump water of Takhata Tonk (S3) was unsuitable for drinking purpose. This study thus concludes that hand pump water in study area is chemically unsuitable for drinking. It is recommended to carry out a proper and continuous water quality program and development of effective management practices for utilization of water resources.
\end{abstract}

Keyword: Tap water, Hand pumps water, Ground water, Drinking water.

\section{Introduction-}

It is well known fact that no life without water. Adequate supply of fresh and clean water is a basic need for all human beings for healthy living. Various human induced activities can modify the natural source of contaminants and initiate pollution load in the receiving water bodies (whittemore et al.1989). Now a day the modern civilization, industrialization, urbanization, human activities and increase in population have lead to fast degradation of our ground water quality and quantity. The development of industries and human activities in developing countries created a number of environment problem like water pollution and their serious effect on human health (Patrick 2003, wang et. al. 2010). Over 85\% population of India used the ground water as the drinking purpose. This ground water is contaminated by industrial effluent, sewage line and numerous human activities, which are unsuitable for drinking. Rajasthan is a state of India which has an area of 342239 lakh square kilo meter. All of the 32 districts of Rajasthan suffer from drinking water pollution. Many researchers gave emphasis on drinking water quality parameters in Rajasthan. Drinking water in 160 villages of Ramgarh tehsil and 6 sites of Alwar district were not found suitable for human consumption (Anil yadav 2004). In ground water of Dudu town EC, TDS were found to be decreases and alkalinity, total hardness were found to be increases after rainfall (Ranjana Agarwal 2009). It was reported that drinking water of Todaraisingh tehsil of tonk is polluted with hardness causing salt (Ashok kumar yadav 2010). The physical chemical analysis of hand pump water of ajmer city reported high concentration of TDS and hardness (shailendra Sharma 2012).Low drinking water quality reported in jaipur, ajmer, churu, alwar, jodhpur, pali, bharatpur, jhunjhunu, sikar and karoli (Saurabh 
Shashank et. al. 2014). Review of literature showed that a large number of studies have been done on drinking water quality in various area of Rajasthan but no study have been undertaken in tonk city of Rajasthan on drinking water pollution yet. The objectives of this study were to analyze the ground water pollution in Tonk city and established the pollution load in drinking water in Tonk city.

\section{Study area}

Tonk district with geographical area of 7194 square kilo meter form north-eastern part of the Rajasthan. Tonk district is comprises of seven sub division and seven tehsils viz. Tonk, Peeplu, Todaraisingh, Deoli, Niwai, Malpura and Uniyara. Tonk is also known as city of Nawab. It is about 100 kilo meter by road from Jaipur near the right bank of Banas River. It is located 25 $5^{\circ} 41^{\prime}$ to $26^{\circ} 34^{\prime}$ North Latitude and $75^{\circ} 07^{\prime}$ to $76^{\circ} 19^{\prime}$ East Longitude. The climate of district is semiarid type. The average mean annual rainfall of district is $531 \mathrm{~mm}$ and has varied from $460.2 \mathrm{~mm}$ at Malpura to $590.04 \mathrm{~mm}$ at Tonk during period 2001to 2010 (GWB 2013). In present study Tonk city is selected to analyze the drinking water pollution in tap water and hand pump water of 5 sampling sites of city (fig-1). All sampling sites of Tonk city depicted in table-1.

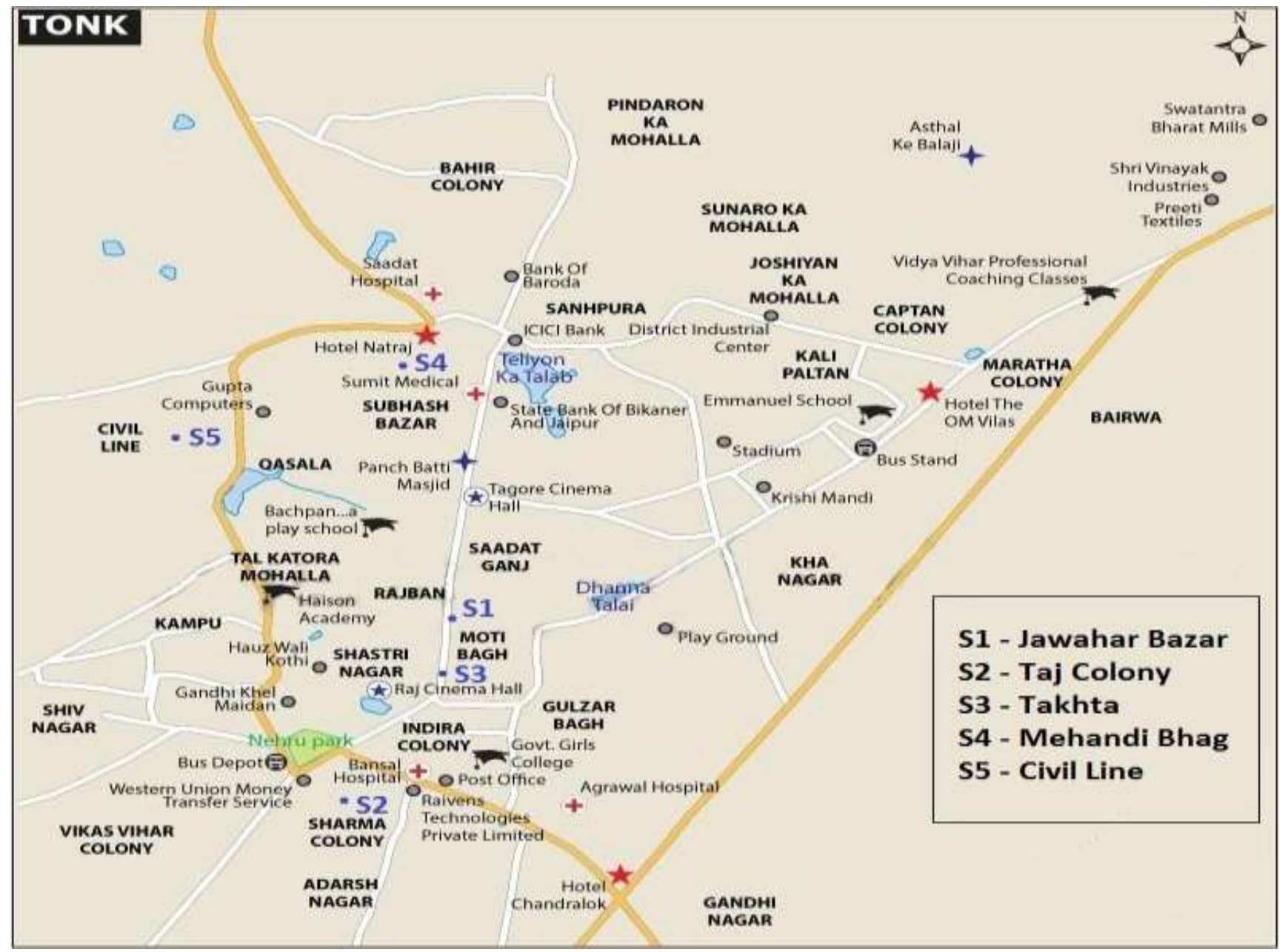

Figure- 1 Map of Study area Tonk City, Rajasthan, India 
Table1-Sampling sites of Tonk city, Rajasthan, India

\begin{tabular}{|c|l|l|c|}
\hline $\begin{array}{c}\text { Serial } \\
\text { No. }\end{array}$ & \multicolumn{1}{|c|}{ Source of water sample } & \multicolumn{1}{|c|}{$\begin{array}{c}\text { Sampling site of } \\
\text { Tonk city }\end{array}$} & $\begin{array}{c}\text { Sample/site } \\
\text { code }\end{array}$ \\
\hline 1 & Tap Water & Jawahar Bazar Tonk & S1 \\
\hline 2 & Tap Water & Taj Colony Tonk & S2 \\
\hline 3 & Hand pump Water & Takhta Tonk & S3 \\
\hline 4 & Hand pump Water & $\begin{array}{l}\text { Mehandi Bagh } \\
\text { Tonk }\end{array}$ & S5 \\
\hline 5 & Hand pump Water & \begin{tabular}{l} 
Civil Line Tonk \\
\hline
\end{tabular}
\end{tabular}

\section{Material and methods}

\subsection{Water Sampling}

Ground water samples of tap water and hand pump water of 5 sampling sites of Tonk city were collected in pre-cleaned and rinsed polythene bottles of 2 liters capacities with precaution. The sampling was done during February 2015 to January 2017 in morning and afternoon hours.

\subsection{Physical-chemical Analysis of water samples}

All the water samples were analyzed for the following physical and chemical parameters $-\mathrm{pH}$, chloride, Total Alkalinity, TDS, and Total Hardness. The analysis of water samples were done in accordance with methods of sampling and test (physical and chemical) for water and wastewater, bureau of Indian standard BIS.

\section{Results and discussion}

The respective observed values of physical chemical parameters of all tap water and hand pump water of Tonk city are illustrated in table 2 . All the results are compared with desirable and permissible limit recommended by bureau of Indian standard BIS10500:2012 depicted in table 3. Statistical parameters of tap water and hand pump water of Tonk city are summarized in table 4.

\section{$4.1 \mathrm{pH}$}

$\mathrm{pH}$ has no direct adverse affect on human health, however a low value below 4.0 will produce sour taste in water. $\mathrm{pH}$ value in the water sample in the ranged from 7.00 to $7.60 \mathrm{mg} / \mathrm{l}$. The minimum $\mathrm{pH}$ value was observed for sample water of sampling sites $\mathrm{S} 1$ and $\mathrm{S} 2$. The maximum $\mathrm{pH}$ value was observed for sample water of sampling sites $\mathrm{S} 4$. The $\mathrm{pH}$ value of all water samples were in the desirable range prescribed by BIS. The graphical representation of $\mathrm{pH}$ in water sample of Tonk city is depicted in figure-2.

\subsection{Chloride}

In water chloride are present in the form of sodium chloride, calcium chloride and magnesium chloride. Chloride value in the water samples ranged from 50.24 to $595.96 \mathrm{mg} / \mathrm{l}$. The minimum 
Chloride value was observed for sample water of sampling sites S1. The maximum chloride value was observed for sample water of sampling sites S3. The chloride concentration in sampling site S1, S2, S4 and S5 were below the desirable limit prescribed by BIS. The chloride concentration in sampling site S3 was above the desirable limit of BIS. The graphical representation of chloride in water sample of Tonk city is depicted in figure-3.

\subsection{Total alkalinity}

The main alkalinity of water is due to presence of carbonate ion and bicarbonate ion. Total alkalinity value in the water samples in the ranged from 185.90 to $452.25 \mathrm{mg} / \mathrm{l}$. The minimum total alkalinity value was observed for sample water of sampling site S5. The maximum total alkalinity value was observed for sample water of sampling sites S3. The total alkalinity concentration in sampling site S5 was below the desirable limit prescribed by BIS. The total alkalinity value in sampling sites S1, S2, S3 and S4 were above the desirable limit prescribed by BIS. The graphical representation of total alkalinity in water sample of Tonk city is depicted in figure-4.

\subsection{Total dissolved solid}

High concentration of TDS in drinking water may result as incidence of cancer, arteriosclerotic heart diseases and cardiovascular diseases. The total dissolved solid in the water samples in the ranged from 270 to $2250 \mathrm{mg} / \mathrm{l}$. The minimum total dissolved solid value was observed for sample water of sampling site S1. The maximum total dissolved solid value was observed for sample water of sampling site S3. The total dissolved solid concentration in sampling site S1, S2, and S5 were below the desirable limit prescribed by BIS. The total dissolved solid concentration in sampling site S4 was above the desirable limit of BIS. The TDS in sampling site S3 was above the permissible limit of BIS. The graphical representation of total dissolved solid in water samples of Tonk city is depicted in figure-5.

\subsection{Total hardness}

Various diseases like nervous system defect and prenatal mortality are correlated with hardness of water. The total hardness in the water samples ranged from 146 to $792.96 \mathrm{mg} / \mathrm{l}$. The minimum total hardness value was observed for sample water of sampling sites S5. The maximum total hardness value was observed for sample water of sampling site S3. The total hardness in sampling sites S1, S2, and S5 were below the desirable limit prescribed by BIS. The total dissolved solid in sampling site $\mathrm{S} 4$ was above the desirable limit of BIS. The total hardness in sampling site S3 was above permissible limit of BIS .The graphical representation of total hardness in water samples of Tonk city is depicted in figure-6.

Table- 2 Analyzed data of sample water of Tonk city, Rajasthan, India

\begin{tabular}{|c|l|c|c|c|c|c|c|}
\hline Serial No. & Parameters & \multirow{2}{*}{ Unit } & \multicolumn{5}{|c|}{ Sampling Sites } \\
\cline { 5 - 8 } & & & $\mathrm{S} 1$ & $\mathrm{~S} 2$ & $\mathrm{~S} 3$ & $\mathrm{~S} 4$ & $\mathrm{~S} 5$ \\
\hline 1 & & $\mathrm{pH}$ & & & & & \\
\hline 2 & Chloride & $\mathrm{mg} / \mathrm{l}$ & 50.24 & 58.28 & 595.96 & 140.03 & 77.99 \\
\hline 3 & Total Alkalinity & $\mathrm{mg} / \mathrm{l}$ & 221 & 227.99 & 452.25 & 311.55 & 185.90 \\
\hline 4 & TDS & $\mathrm{mg} / \mathrm{l}$ & 270 & 278 & 2250 & 579 & 412 \\
\hline 5 & Total Hardness & $\mathrm{mg} / \mathrm{l}$ & 162.14 & 165.16 & 792.96 & 241.52 & 146 \\
\hline
\end{tabular}

Table-3 Standard of drinking water of BIS 


\begin{tabular}{|c|l|c|c|c|}
\hline Serial No. & \multicolumn{1}{|c|}{ Parameters } & $\begin{array}{c}\text { Desirable } \\
\text { limit }\end{array}$ & $\begin{array}{c}\text { Permissible } \\
\text { Limit }\end{array}$ & Unit \\
\hline 1 & $\mathrm{pH}$ & $6.5-8.5$ & ----------- & ------- \\
\hline 2 & Chloride & 250 & 1000 & $\mathrm{mg} / \mathrm{l}$ \\
\hline 3 & Total Alkalinity & 200 & 600 & $\mathrm{mg} / \mathrm{l}$ \\
\hline 4 & Total Dissolved solid & 500 & 2000 & $\mathrm{mg} / \mathrm{l}$ \\
\hline 5 & Total Hardness & 200 & 600 & $\mathrm{mg} / \mathrm{l}$ \\
\hline
\end{tabular}

Table-4 Statistical data of sample water of Tonk city, Rajasthan, India.

\begin{tabular}{|c|l|l|c|c|c|}
\hline $\mathrm{S}$ & Parameters & Unit & Minimum & Maximu & Average \\
\hline 1 & $\mathrm{pH}$ & & 7 & 7.60 & 7.28 \\
\hline 2 & Chloride & $\mathrm{mg} / \mathrm{l}$ & 50.24 & 595.96 & 184.5 \\
\hline 3 & Total Alkalinity & $\mathrm{mg} / \mathrm{l}$ & 185.9 & 452.25 & 279.73 \\
\hline 4 & TDS & $\mathrm{mg} / \mathrm{l}$ & & & \\
\hline 5 & Total Hardness & $\mathrm{mg} / \mathrm{l}$ & & 2250 & 757.8 \\
\hline
\end{tabular}




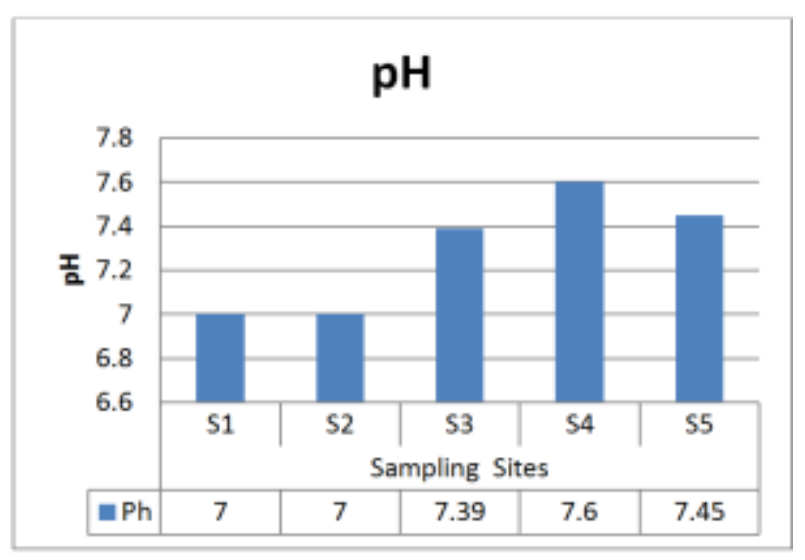

Figure 2.Variation in $\mathrm{pH}$ with sampling sites of Tonk City

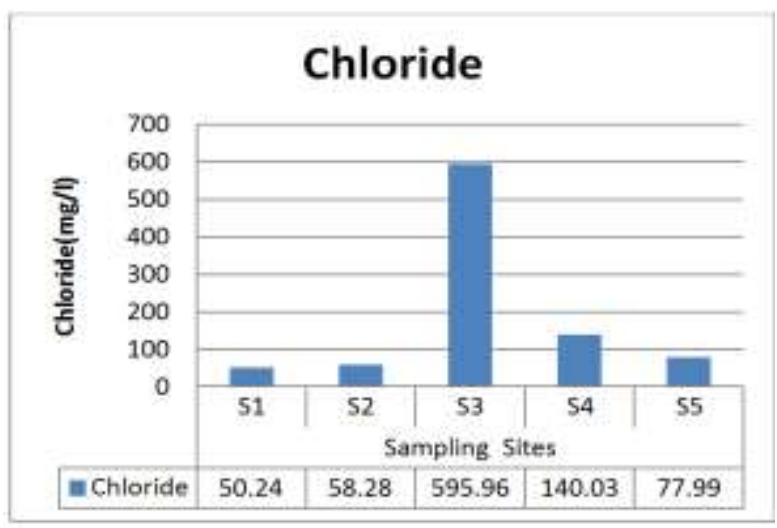

Figure 3.Variation in Chloride with sampling sites of Tonk City

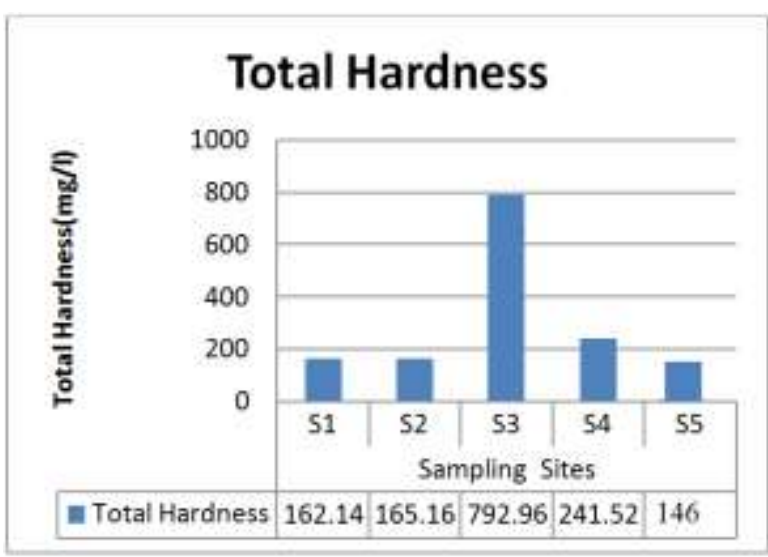

Figure 6.Variation in Total Hardness with sampling sites of Tonk City

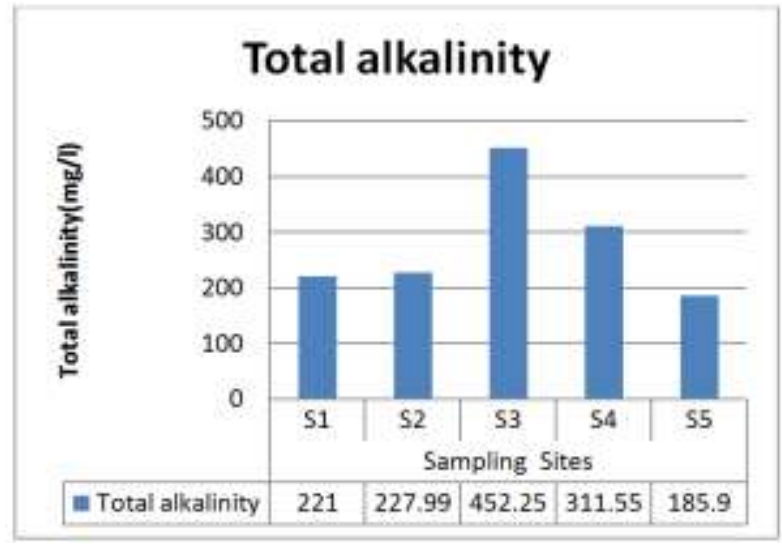

Figure 4.Variation in TA with sampling sites of Tonk City

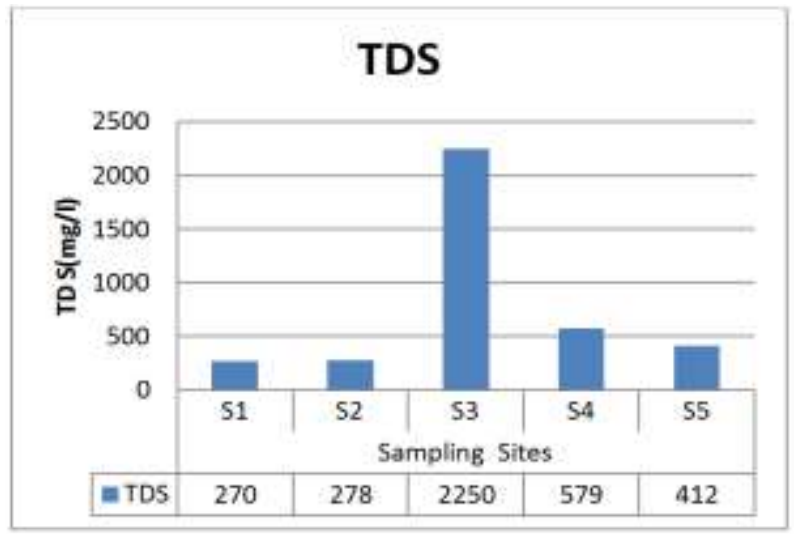

Figure 5.Variation in TDS with sampling sites of Tonk City 


\section{Conclusion}

The analysis of water samples collected from different sites of Tonk city revealed that water samples of Jawahar Bazaar Tonk (S1), Taj Colony Tonk (S2), Mehandi Bagh Tonk (S4) and Civil Line Tonk (S5) were found to be suitable for drinking purpose but hand pump water samples of Takhata Tonk (S3) was not found to be suitable for drinking purpose on the basis of water quality parameters of Indian standard of drinking water prescribed by bureau of Indian standard IS10500.2012. Such hand pump water requires proper treatment before used by local community.

\section{References}

[1] Agarwal R. (2009), Study of physic-chemical parameters of ground water quality of Dudu town in Rajasthan. Rasayan journal of chemistry vol.2 no.4, 969-971

[2] BIS (1987) method of sampling and test (physical and chemical) bureau of Indian standard, Manak Bhawan, New Delhi.

[3] BIS (1991) 10500:2012 drinking water quality parameters, bureau of Indian standard, Manak Bhawan, New Delhi.

[4] CGWB (2013) central ground water board, ground water information Tonk district Rajasthan, western region tonk.pp-1-4

[5] Mathur P. Tomer P. (2011) physical chemical analysis of ground water of Ajmer city in Rajasthan. International journal of chemical vol.9 (3) pp 1319-1333.

[6] Patrick L. (2003), Toxic metal and antioxidant: part 2.The role of antioxidant in arsenic and cadmium toxicity. Altern Med Rev 8:106-128.

[7] Shashank S, Singh D, Tiwaris (2014).Drinking water quality of Rajasthan Districts. Journal of basic and applied engineering research. Vol.1, no $10 \mathrm{pp} 105-109$.

[8] Wang M, Xu Y, Pan S, et al (2010), Long term heavy metal pollution and mortality in Chinese population :an ecologic study. Bio trace element Res 1-18.

[9] Whittemore DO, Greggor KMM, Marotz GA (1989) effect of variation in recharge on ground water quality. J Hydrol 106:131-145.

[10] Yadav A.K. Khan P. (2010) water quality index assessment of ground water in todaraisingh tehsil of tonk, rajasthan.A green approach journal of chemistry 7 s428-s432.

[11] Yadav Anil (2004) study of water pollution in Alwar, Rajasthan, India. Thesis submitted in university of Rajasthan, Jaipur 